\title{
Lira Lírica
}

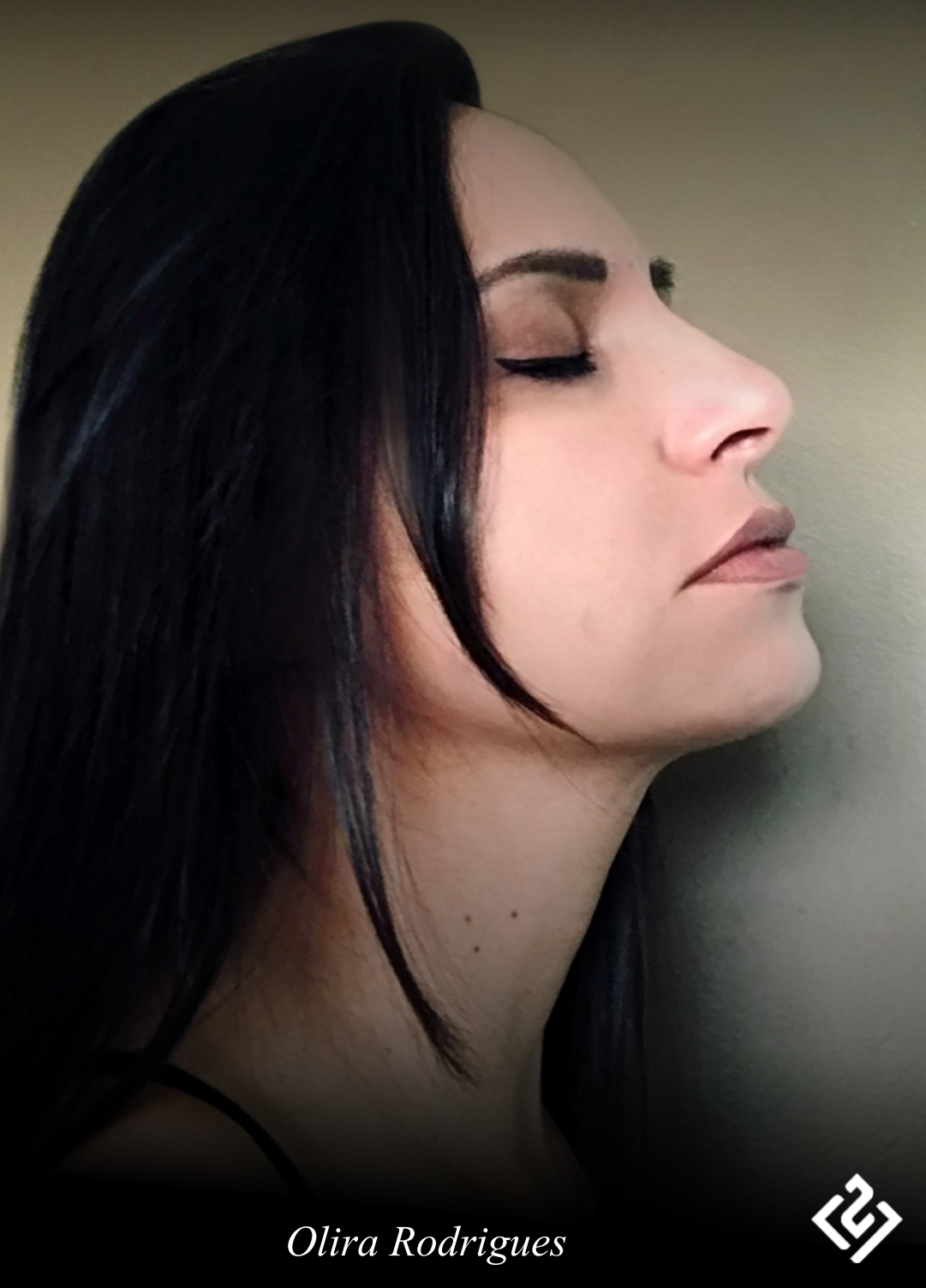




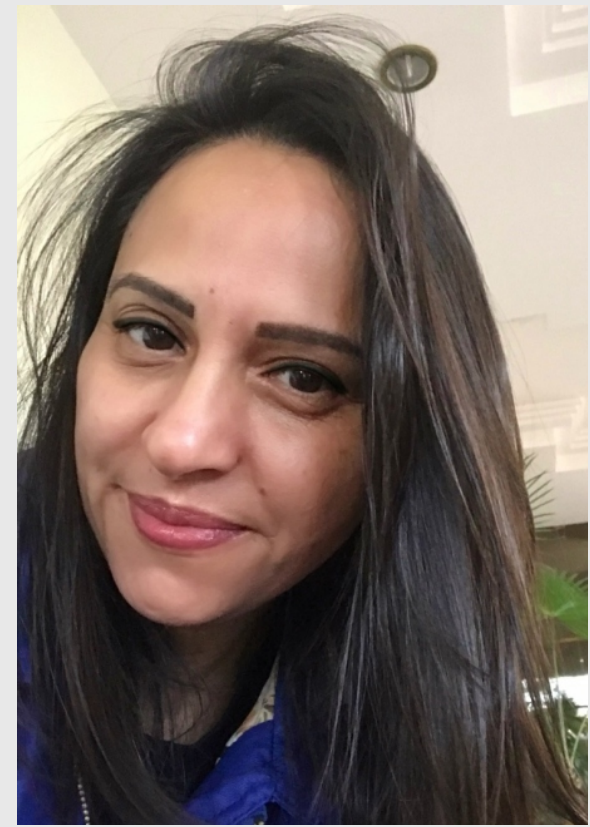

Olira Saraiva Rodrigues

Graduada em Letras pela Universidade Estadual de Goiás (UEG). Mestra em Educação pela Pontifícia Universidade Católica de Goiás (PUC-Goiás).

Doutora em Arte e Cultura Visual pela Universidade Federal de Goiás (UFG). Pós-doutora em Estudos Culturais pelo Programa Avançado de Cultura

Contemporânea da Faculdade de Letras da Universidade Federal do Rio de Janeiro (UFRJ). Profissionalmente, docente da Universidade Estadual de Goiás (UEG). 
Lira Lírica 
(C) UEG - 2019

UNIVERSIDADE ESTADUAL DE GOIÁS PRÓ-REITORIA DE PESQUISA E PÓS-GRADUAÇÃO BR-153 - Quadra Área Km 99, 75.132-903 - Anápolis - GO

\section{Reitoria}

Ivano Alessandro Devilla (Reitor)

Pró-Reitoria de Pesquisa e Pós-Graduação

Everton Tizo Pedroso (Pró-Reitor de Pesquisa e Pós-Graduação)

Coordenadora de Projetos e Publicações

Coordenação Editorial: Elisabete Tomomi Kowata

RevisãoTécnica: Danila Laiana da Silva Mello

Thalita Gabriele Lacerda Ribeiro

Câmpus de Ciências Exatas e Tecnológicas - Henrique Santillo Elton Fialho dos Reis (Diretor Educacional)

Revisão Geral

Olira Saraiva Rodrigues

Capa e Projeto Gráfico

Witter Martins Rodrigues 
Olira Rodrigues

Lira Lírica

ANÁPOLIS-GO|2019 
A reprodução não autorizada desta publicação, por qualquer meio, seja total ou parcial, constitui violação da Lei no 9.610/98.

Depósito legal na Biblioteca Nacional, conforme decreto $\mathrm{n}^{\circ} 1.825$, de 20 de dezembro de 1907.

\section{Catalogação na Fonte}

Comissão Técnica do Sistema Integrado de Bibliotecas Regionais (SIBRE), Universidade Estadual de Goiás

R6961 Rodrigues, Olira.

Lira Lírica / Olira Rodrigues. - Anápolis: UEG, 2019.

$62 \mathrm{p}$

ISBN 978-85-5582-067-0 (e-Book)

1. Poemas. 2. Poemas líricos. I. Título

CDU 82-1

Elaborada por: Ceila da Silva Rodrigues CRB 1/2218

Esta obra é em formato de e-Book e foi produzida com recursos da própria autora. A exatidão das referências, a revisão gramatical e as ideias expressas e/ou defendidas nos textos são de inteira responsabilidade da autora.

\section{Impresso no Brasil \\ Printed in Brazil




\section{INSPIRAÇÃO}

Assim apresento esta obra versificada em musicalidade.

Lira sou e lírica estou em uma escrita de respiros, suspiros, transpirações, que, por inúmeras vezes, expirou em aspirações sequer registradas. Uma produção à flor da pele, com uma apreciação que impele uma ausência, muitas vezes, de interpretação, para que não interpele seus sentidos, paradoxalmente. Por meio da arte em poesia, a leitura pretende despertar a sensibilidade no leitor.

O livro consiste em uma coletânea de 40 poemas, que realçam a sintática e a semântica a partir de escritas inquietantes. As temáticas que se apresentam são contemporâneas, com uma diversidade que promove um entretecer de pensamentos, emoções, desejos, considerações, que incitam interpretações intelectuais e afetivas, em uma concepção reflexiva da vida. Os textos são tecidos em enredos emaranhados de literatura, ciência, cultura, relações humanas e valores, produzindo posicionamentos em interlocução com o leitor.

O processo de produção germina por meio de uma relação intimista, diante de uma sensibilidade afetada pelos afetos. A verve da escrita reverbera visões, sons, sabores, aromas e toques, cujas versões versejam palavras singelas e, compativelmente, sedutoras a leitores sensíveis, amantes da literatura.

Sentir é o convite para degustar as essências e fragrâncias dessas poesias, como sopros e sussurros na provocação de arrepios e calafrios silentes, na alma, a cada leitura. Lira Lírica é uma obra para ser apreciada por meio da fruição de uma leitura, para além das linhas e entrelinhas, pelos alinhavos plurissensórios. 



\section{Sumário}

$\begin{array}{rr}\text { Inspiração } & 07 \\ \text { A vida } & 11 \\ \text { Acessibilidade } & 12 \\ \text { Agruras } & 13 \\ \text { Amizades } & 14 \\ \text { Amor e desamores } & 16 \\ \text { Amplexos } & 17 \\ \text { Análise sintática } & 18 \\ \text { Aproximações e distanciamentos } & 20 \\ \text { Ausência } & 21 \\ \text { Bibliotecas contemporâneas } & 22 \\ \text { Choro } & 23 \\ \text { Chuva } & 24 \\ \text { Con(fusão) } & 25 \\ \text { Contexto digital } & 26 \\ \text { Cora em cores } & 27 \\ \text { Des(conectados) } & 29 \\ \text { Desejo } & 31 \\ \text { (des)Respeito! } & 32 \\ \text { Deus } & 33 \\ \text { Discrepância } & 35 \\ \text { Envelhecer } & 36 \\ \text { Filhos } & 37 \\ \text { Flores personificadas } & 39 \\ \text { Inovar } & 41 \\ \text { Liderança } & 42 \\ \text { Líderes } & 43 \\ 44\end{array}$




$\begin{array}{rr}\text { Morte } & 45 \\ \text { Morte em vida } & 46 \\ \text { Mulher! } & 47 \\ \text { Música é proparoxítona } & 48 \\ \text { Ócio criativo } & 49 \\ \text { Olhares } & 50 \\ \text { Paixão } & 52 \\ \text { Pitaia } & 54 \\ \text { Poetize-se } & 55 \\ \text { Sensorialidade } & 56 \\ \text { Sociedade Enferma } & 57 \\ \text { Tempo } & 58 \\ \text { Trabalho } & 59\end{array}$




\section{A vida}

A vida é um lapso

- Colapsos alijados por paixões -

Que engendra incólumes tensões,

Ladeadas por incrustadas e recrudescidas inquietações.

A composição do ser humano

- Alma, corpo e mente -

Quando desmembrada e repartida,

Conspurca a unicidade hegemônica, em contrapartida.

Dessarte, desenlear e destrinçar a trama tríade envolta, Disjungir e cindir a trança que envolve o ser, Pretere o entremeio integral, Reprimindo a sinestesia orgânica e original. 


\section{Acessibilidade}

Equidade e dignidade!

Pois particularidades

Podem segregar pessoas

Em condições de especificidades

Físicas, intelectuais,

Mentais, sensoriais.

Inúmeras barreiras,

Impedimentos culturais,

Políticos, informacionais,

E, mesmo, comportamentais.

Aplicação da tecnologia nas humanidades, Em uso e apropriação para acessibilidade, Promove igualdade, democracia, Liberdade, cidadania.

Entre embates e debates, Independência às pessoas com deficiência, São passos que precisam ser dados, Assertivos, acessivos, continuados. 


\section{Agruras}

Em silenciosas e frias reflexões,

Há angústias e aflições,

Em olhares vazios,

Convívios frios,

Relacionamentos avulsos,

Choros convulsos.

Decepções álgicas,

Memórias nostálgicas,

Instalam caos interiores

Como processos ulteriores.

Nulidades cotidianas,

Injúrias levianas,

Pressões sociais,

Amarguras letais,

Em labirintos sôfregos,

E enredos sacrílegos.

Manobras ardilosas são vitais,

Para desabafar, expurgar culpas, Extravasar o que incomoda, sufoca, Reprime, aprisiona, provoca, Como todo arsenal de ferimento, Sedento de alento. 


\section{Amizades}

Ah! Como é bom ter amigos!

Sim, amigos verdadeiros, conselheiros, Companheiros, artistas e arteiros.

A Bíblia revela que há amigos mais chegados que irmãos.

Por apreço, ternura e afeição,

Quase sempre com predileção,

A admiração é fator de consideração.

Amizade sincera se estima,

Cultiva e legitima

O valor especial,

Mais que um laço parental.

A canção expressa que amigo é coisa pra se guardar

Debaixo de sete chaves.

Sorrisos, segredos, presenças suaves,

Intensificam sintonias agudas e graves.

Na amizade, não há vaidade,

Mas cumplicidade, fidelidade,

Reciprocidade e até criticidade.

Raros amigos confidentes

São refúgios, refrigérios,

Em momentos de desesperos,

Compartilhamos tudo, sem exageros.

Ah! Como faz bem um afago amigo. 
Amigos atuais ou antigos, De agora ou de outrora, Nunca joios, mas trigos,

São aconchegos e leais abrigos. 


\section{Amor e desamores}

Nem tudo são flores,

Diante dos desamores,

Os dissabores e amargores,

Com rancores, temores e tremores,

Geram dores, geradores de tumores.

Sejam escritores, doutores,

Narradores, pensadores,

Ou puros sonhadores,

As dores em momentos opressores

Se instalam nos interiores.

Já o amor é ardor, calor, fervor,

Furor, fulgor, vigor,

Com cor, odor, candor,

No voo de um beija-flor,

Como um esplendor encantador.

O senso de humor,

Conciliador e alentador,

Opera como reparador,

Num clamor enternecedor

E libertador, para recompor

O motor a vapor emancipador. 


\section{Amplexos}

Conexos, com nexos

Deixa-nos perplexos,

Cujos reflexos

Nada concâvos, mas convexos,

Sentimos gratos, genuflexos.

Um abraço, feito um laço

No (com)passo, sem nenhum passo

Um traço curvo, no braço,

Sem espaço, ameaço

Não soltar nenhum pedaço.

No entanto,

O recanto,

Se afaz de desencanto,

Quando o outro, ora infanto,

Distancia-se, metamorfoseando o acalanto em pranto. 


\section{Análise sintática}

Disseram-me que eu era sintática,

Diante da preocupação com múltiplas combinações possíveis, Para significados completos e compreensíveis.

A sintática é estrutural,

Organiza, harmoniza,

Períodos simples, compostos,

Sujeito, predicado,

Tornando tudo descomplicado.

Termos essenciais, integrantes, Acessórios, vocativos, A análise sintática determina a função, Mediante sentido, posição, disposição, Que ocupa na oração.

Enquanto a morfologia não analisa o texto, A sintática se constitui de acordo com o contexto.

Por meio de mecanismos como regência e concordância, O solecismo seria sua total inobservância.

Quem aponta minha característica, Por conta de minha performance linguística?

A semântica,

Com pura interpretação e sentido,

Descolada de termo preestabelecido.

Na verdade, sou estilística, Com uma conexão histórica, 
Entre a poética e a retórica.

Apenas estilo, expressividade, Personalidade, identidade. 


\section{Aproximações e distanciamentos}

Afinidades, conformidades, Semelhanças, bonanças:

Relações com menores tensões.

Divergências, indiferenças, Ausências, prepotências:

Relações por piores intenções.

Diálogos. Histórias. Memórias.

Confrontos. Conflitos. Atritos.

Cenários sombrios, frios.

Por destemperos, há os dissabores,

$\mathrm{E}$ a arte do conviver

Pode ferir, doer, fazer sofrer.

A paz do perdão, Traz cor ao coração,

Com (de)(cor)(ação) quente, aquiescente.

Insensatez ou coerência?

Entre penumbra eluminescência, Prefira a esplêndida essência. 


\section{Ausência}

Emudeço no silêncio de sua ausência,

Sem sequer haver aquiescência,

Cujo afastamento representa um hiato

Do que já foi ditongo,

Com a tônica na junção,

Do que já foi dedicação.

Dias desbotados,

Paisagens apagadas,

Sem presenças alentadas,

Com carências descoradas.

Desenhos vazios,

Pinturas desfalecidas,

Contornos sombrios,

Em telas desvanecidas.

Recuos, separações, saudades, solidões, Fendas, gretas, gritos silenciados,

Fissuras, ranhuras, buracos amedrontados,

Em vidas desvinculadas, em mundos de ineptidões.

Inexpressivo é o ostracismo, Acrômico é o distanciamento.

Fragmento, ressentimento,

Saudosismo, antagonismo. 


\section{Bibliotecas contemporâneas}

Se na antiguidade os astecas dominaram o México central,

$\mathrm{Na}$ contemporaneidade, as bibliotecas conectam-se à cultura digital,

Com íntimos desejos, histórias, imagens,

Por ventura, em aventuras, desventuras e viagens,

Suscitam leituras com novas paisagens.

Bibliotecas com coletâneas, coleções, seleções,

Repertórios, repositórios, copilações, compilações

Basculam suas tradições e contradições,

Ressoando consonâncias e dissonâncias,

Em fabular e confabular ressonâncias.

Cultura de leitura em incessante semeadura,

Com conectividade na contemporaneidade.

Práticas inovativas, com tecnologias assistivas,

Consentem as acessibilidades, inclusive

Com possibilidades, de outras discursividades. 


\section{Choro}

O pranto em dias cinzas, Sem canto em noites frias e ranzinzas, Aliviam, abreviam, Astutos lutos que tardiam.

As lágrimas de grimas, Os choros de fins de namoros, Transformam-se em matérias-primas Para tratar destratos e desaforos.

Chorar depura, Ajuda na cura, Tempera, recupera, Regenera a intimista atmosfera.

Os soluços, ora vertidos

De lamentos por não acolhimentos

Maturam sentimentos abatidos

$\mathrm{Na}$ colheita de discernimentos. 


\section{Chuva}

A chuva chora

Com cheiros e memórias

Da infância migratória,

Em trajetórias e histórias

Ilusórias, irrisórias e declaratórias.

Água de cheiro,

Capim de cheiro,

Perereca de banheiro,

Chuva

Não sugere chuveiro.

O choro da chuva

Desenxovalha e preenche

- Ambivalente e reincidente -

Brechas, frestas, fendas,

Do gauche resiliente e incoerente cognoscente.

Por capricho, o chuvisco

Rechaça o recheio faiscante,

Do arrocho carrapicho

E aconchego escorchante,

Em conchavo com o pluvioso plurissignificante. 


\section{Con(fusão)}

Por que con(fundir) é pejorativo?

Se desmembrarmos o vocábulo,

Interpretamos com unir, combinar,

No entrelaço do in(corpo)rar.

Já sei!

Confusão, o substantivo, tem sentido de desalinho,

Desarranjo e até conflito,

Por isso que emerge um sentimento aflito.

A confusão traz obscuridade,

Nebulosidade, complexidade.

Mas, dependendo do contexto,

É um começo para se chegar à realidade.

Confundir o pensamento

De algo consolidado,

Inquieta e desestabiliza.

Porém, ao percurso do esclarecimento,

Reforçam-se as convicções, definições,

Ou se conduz a reestruturadas opiniões, redefinições. 


\section{Contexto digital}

O contexto digital, defluindo posições, Composições e recomposições, Na cultura contemporânea, Imprimem-se vivências, Do material ao (i)material, em confluências.

Léxicos e ícones em vetores de devir, Espaços singulares com arfantes do porvir, Modus operandi no entremeio das pulsões, Como lugares de confrontos e tensões, Em redes semânticas de conexões.

Dentre a lista de conquistas intimistas, A conectividade era ínvia, utopista, Haja vista a via realista.

Hoje, experiências benquistas da sociedade De maior e menor idade. 


\section{Cora em cores}

Cora Coralina,

Com alma de menina,

Escreve sua história

E revela sua memória.

Sua leitura desafia

Atravessamentos.

Seus afetos e desafetos,

Sentidos e ressentidos,

Retinem renitentes,

Escritas latentes.

O rio e a terra vermelha,

Elementos de sua casa,

Traduzem sua relação sanguínea,

Margens rúbeas metafóricas,

Visceral em sua essência

Em fluxos de consciência.

Seus doces aromatizantes,

Em tachos rosados de cobre,

Dão sabor e sintonia à poesia,

Adoçam os olhos com sinestesia.

Cora colore de sensibilidade

Retratos da cor local

Becos e bicas de Goiás

Que ecoam e escoam

Versos e reversos, 
Inversos e controversos.

Reflexiva, singular, A poética de cores coralinas

Abrasam e abraçam

Corações errantes, Inebriantes de cores vibrantes. 


\section{Des(conectados)}

Abismos urbanos sociais.

Almas que não dialogam.

Divergências epistêmicas, ideológicas, comportamentais.

Pensamentos paradoxais.

Comunicações turvas, truncadas.

Interpretações mutiladas.

Diálogos suspensos.

Barreiras tropeçantes invisíveis,

Em antíteses perceptíveis.

Esplêndidos intelectos,

Letrados cientistas,

De naturezas reflexivas,

Depuram e capturam

Labirintos mentais,

Com imperfeições formais

Os rigores conceituais.

Fagulhas de monólogos angustiantes, Em temporalidades determinantes, Com (des)interesses flutuantes, Emergem sensações afetantes.

Voz veraz e viva, cativa

Nos dois sentidos:

De prisão e paixão,

Com odor adocicado, 
Concorde um vinho suavizado.

No constructo da interação social

É visceral

O abrir e fechar de pálpebras

E o estalar de dentes

Persistentes e reincidentes.

Na relação face a face

Mesmo que canhestra

- Que não é canhota e destra, Mas simplesmente tímida -

Em off lines experiências,

Que se atenuam as discordes incidências. 


\section{Desejo}

Vejo. Cortejo. Ensejo. Lampejo.

Corpo. Hormônio. Respiração.

Músculo. Sangue. Coração,

Que fibrila, tremula em vibração.

Assimé a juventude,

Com viço e verdor da idade.

Paixão ávida, impávida,

Símile à apetência de uma grávida.

Na maturidade, díspar ao frescor da estação,

É transmutável a paixão,

Refulgente em essência,

Sêmen da existência.

Nas entranhas, no mais íntimo,

Aspiramos o silêncio, a quietude,

Assim é a maturescência,

Que transcende o voraz, o fulgaz,

Por um ponto de referência.

Pura inteligência ter ciência,

Por experiência ou prudência,

De consequências por incoerências. 


\section{(des)Respeito!}

Racismo,

Por ceticismo, não cri.

Até que um dia descobri,

Por histórias e relatos,

Aqueles atos insensatos,

De fatos de maus tratos

E muitos em anonimatos.

Rejeito o preconceito

Rarefeito, liquefeito,

De feitos imperfeitos,

Queincitam

- A torto e a direito -

Palavras sem preceitos,

Em Orações sem Sujeito.

A raça humana é uma só, Indígenas, portugueses, holandeses, Italianos, negros, árabes, japoneses.

Tudo, é questão de etnia, Em polifonia e heterogenia, Alcançando em harmonia e anacronia, A sintonia com a plurietnia. 


\section{Deus}

Deus é poesia, Pura poesia.

Poesia com maestria, Que anestesia, analgesia, Dores e vazios de almas, Amalgamadas de traumas.

Seu amor é inexplicável, imensurável, Infindável e indissociável, De sua misericórdia e graça, Que em tudo perpassa.

Como é bom conhecê-Lo, E senti-Lo, a partir do zelo, Esmero e desvelo.

Ele conhece cada fio de cabelo, Cada sonho e pesadelo, Sem sequer um apelo.

A trindade: Pai, Filho e Espírito, Acolhe o coração sofrido e contrito, Para acalentar e aquietar, Em embalo e aconchego, Remanso e assossego.

Deus é amor!

Amor que constrange,

No que tange à magnitude, Que extravasa e ultrapassa, 
Toda a completude e plenitude.

Éinício, meio e fim,

Ontem, hoje e amanhã,

Onipotente, onipresente e onisciente;

Portanto, estejamos cientes

E conscientes que não somos autossuficientes. 


\section{Discrepância}

Há palavras que lavram e escalavram,

A hegemonia trai a homogenia

E não há simetria como na poesia.

Ora extravagantes, ora distantes,

Somos seres inconstantes, afetantes, aflitantes.

Assim somos e nos compomos

O que conduz é o que produz,

Que induz e seduz,

Não o que traduz,

Pois jamais reproduz.

De silêncios asfixiados, interpretados,

Imensos contrassensos

Ofensos, suspensos e tensos,

Seguimos espraiados, letargiados,

Discordantes, dissonantes, discrepantes. 


\section{Envelhecer}

Envelhecer é entardecer a cada dia, Em ousadia que discorda da covardia, Diante do enfrentamento da vida, Compreendida a consciência da partida.

O desgaste, em contraste com a ruína, Atina e dispara a disciplina, Que abomina práticas repentinas, Que culminavam em puras adrenalinas.

Os sinais de expressão são partes dessa evolução, De quem engatinhou no chão, Ameninou-se, adolesceu-se, tornou-se adulto, Em direção implacável ao sepulcro.

Maturidade deveria vir com a idade, Porém, lamentavelmente, muitos querem

Manter-se jovens de corpos,

Quando outros, de alma e mente, Que não mentem, Intrinsecamente, permanecem jovialmente latentes.

Para mim, são pessoas experientes, Independentes, prudentes e providentes, Tendentes a amores surpreendentes. 


\section{Filhos}

Criança, herança,

Presente, descendente,

Biológico ou por adoção,

Inunda todo nosso coração.

Febre, dor, preocupação,

Madrugadas, hospitais, inalação,

Doença, cirurgia, cuidado,

Com todo o tempo dedicado,

Não importa a dificuldade,

Por um amor de singularidade.

Fruto, rebento, prole, verve.

Sangue, carne, amor que ferve,

Sem limite ou condição,

$\mathrm{Na}$ junção da razão e emoção.

Educar é árduo,

É sorrir, chorar, sofrer, cuidar.

Amor do ventre à eternidade,

Que medra e lateja vivacidade.

Eterno colo,

Simetria de olhares,

Sinergia entre milhares,

Em quaisquer tempos e lugares.

Seres pequenos e frágeis,

Em tempos que não congelam. 
E mesmo grandes e distantes, Amores imensuráveis e constantes. 


\section{Flores personificadas}

Seja flor, seja cor, seja amor,

Com frescor, primor.

Conviver em jardins de pessoas

Que sejam poucas, mas boas,

Suavizam a rudeza, rijeza.

Fortalecem a fadiga, fraqueza.

Os espinhos permanecem sozinhos,

Trilham outros caminhos.

Mesquinhos,

Nem recebem carinhos.

Flores embelezam.

Flores alegram.

Parques, praças, quintais.

Onde estiverem,

São essencialmente ornamentais.

O perfume que exalam, Intercala com sua beleza e graça, Que congraça e engraça, Por onde passam.

A essência de lavanda

$\mathrm{Na}$ varanda

Resvala o aroma

Que te toma

E te leva até Roma, Alastrado como um rizoma. 
Quero ser flor!

Cultivada, regada.

Flor que brote

No bosque e busque

O deslumbre

Que nada ofusque.

O momento de despetalar chegará.

Semear a florescência

Presentifica a influência

E transcendência de toda nossa (cons) ciência. 


\section{Inovar}

Inovar - inova o ar.

Pura novidade?

Ou criatividade?

Ou seria inventividade?

É sim atividade,

Com nova capacidade,

Imposta pela modernidade,

Diante de potencialidade e oportunidade,

De competitividade,

Gerando eficiência, eficácia e efetividade.

Inovação, é nova ação,

Mais que renovação,

Sendo revolução, reconfiguração,

Na busca da excelência,

Por meio de transformação.

Um processo de ruptura,

De quebra de paradigma,

Como vetor de desenvolvimento humano,

Para impactar, desbravar, destravar,

Com ou sem tecnologias,

$\mathrm{O}$ incentivo e cultivo,

De novas ideologias. 


\section{Liderança}

A superioridade não está na simples autoridade, Mas nas relações proporcionadas, Como estratégia de hombridade, Demonstrando competência e capacidade.

O sofisticado é ser simples, O desafio é ser humilde, E o protagonismo deve ser compartilhado, Com talentos encorajados.

Sensatez, confiança, Responsabilidade, segurança, Garra, carisma, integridade, São características em potencialidade.

E o sucesso vem do engajamento, Da paixão, do envolvimento, Do equilíbrio racional, E da inteligência emocional. 


\section{Líderes}

Há líderes que conduzem com inexperiência, Incompreensão, incapacidade, ininteligência, Cujos resultados são referências, De incipiências e ineficiências.

Outros lideram com sapiência, Conhecimento, entendimento, domínio, Cujos atributos de predomínio, Reconhecem a excelência.

Situações de conflito, Que geram atrito, Evocam planos de ação, Para a resolução.

E o bom líder não é chefe, O bom líder inspira, Motiva, socializa, influencia, Com autonomia e articulação Toda a equipe em cada função. 


\section{Luminosidade fraudulenta}

Um mundo de encantos expõeidentidades

De aparências, deformidades,

Diante de uma sociedade

Distante da integralidade.

Incompreensibilidades, estranhamentos,

Desconcertantes relacionamentos,

Movimentos comportamentais,

Que perpassam as urdiduras sociais.

A complexidade dos simulacros,

Na sociedade do espetáculo,

Não preenchem vazios da alma,

Ocasionando traumas.

Seres humanos entorpecidos

Por uma modernidade não sincrética

Tem reverberado em febres,

Sem aumento de temperaturas.

Aflorando dados anômalos

Da sociedade nessa tessitura.

Aceitabilidade e aprovação

No mundo de representação

Exercem efeitos anódinos, apenas paliativos,

Em mazelas e distúrbios cativos. 


\section{Morte}

O corpo efêmero,

Finito, fugaz,

Fenece lentamente.

Tensamente.

Adormecer e nunca acordar

Desintegrar-se, em um último espirar

É a única certeza

Que deságua na correnteza

Contra a pseudo fortaleza

De toda nossa natureza.

Eternizar-se,

Perpetuar-se no interior de outrem,

Lança a lembrança

Da índole, do lirismo,

Da hipérbole, do eufemismo.

Assim, o conforto

Do esvair, do dissipar,

No último suspirar e arfar

É o que marca, o que difere,

E o que interfere.

Não o que fere. 


\section{Morte em vida}

Morrer sem deixar recordação,

Em nenhum sistema cardiovascular

- Com sangue, coração, pulsão -,

Nunca viveu de fato,

Desde feto, é expectro nato.

O contato direto,

Cuja epiderme arrepia,

Faz da utopia, realidade,

Do devaneio, verdade.

O medo de se machucar

Émedular.

Mas nunca sentir

O coração esbaforir

E, mesmo, partir,

Nunca viveu completamente

De alma, corpo e mente. 


\section{Mulher!}

Doce, na intensidade de um chocolate,

Vibrante, de nuance e matiz escarlate, Assim é a versão feminina, Definida desde menina.

Jovens, como relâmpagos penetrantes, Padecem, entorpecem, esmaecem, Elutam, exultam, triunfam, Como raios pungentes e dilacerantes.

Velhas, nas dobras e desdobras da vida, Aporias que cravaram feridas, Lapidam os rumores e dores, Em talhas polidas de novos valores.

Ora rijas, intrépidas, destemidas, Ora dilaceradas, oprimidas, deprimidas, Imprimem lastros e rastros desmedidos, Em nada tímidos sucessos bem sucedidos.

Com conquistas benquistas, Tornam-se protagonistas, Do antagonismo da narrativa sem memória, Como ativistas, linguistas e otimistas da história. 


\section{Música é proparoxítona}

\section{Músicas}

Com letras problemáticas, sarcásticas e enfáticas,

Composições soam reações carismáticas ou dramáticas.

Harmônicas ou antagônicas,

Musicalizam monofônicas, polifônicas e afônicas.

Folclóricas, metafóricas, geográficas,

Românticas, eletrônicas ou clássicas

São sempre idiossincrásicas.

Em melodias analgésicas e anestésicas,

Afinam sinestesias cinestésicas e cinésicas.

Artísticas, míticas, políticas e científicas, Retinem filarmônicas físicas e metafísicas.

Dinâmicas ou sistêmicas entoam polêmicas,

De epistêmica endêmica, ecoam epidêmicas.

Em dissonâncias às sonâncias, Sinfônicas consonâncias e ressonâncias

Compõem métricas céticas e ecléticas, Na desafinação dialética à poética. 


\section{Ócio criativo}

Interatividade, mídias sociais,

Comunicabilidade, paradigmas consensuais.

Estado de torpor, perspectivas esvaziadas,

Tensões teóricas não praticadas.

Comportamento controlado?

Pensamento manipulado.

Novos pombos nas caixas de Skinner,

Modus operandi da cultura contemporânea,

Em que se encontram usuários de aplicativos,

Sem lastros críticos, criativos e ativos.

Modernos sistemas computacionais,

De elevadores a computadores,

Planos e atividades operacionais,

Refletem oprimidos e opressores.

Dependência de conexão,

Sem fundamento utilitário ou de realização.

Raquítica revolução. Obsoleta contribuição.

Redes sociais (des)integradas,

Práticas culturais (des)niveladas,

Urgem por pensamentos rumo à solução,

Em que o ócio criativo conduza à evolução. 


\section{Olhares}

Olhos são janelas da alma,

Atravessando o âmago do ser,

São duplos, tamanha importância,

Confessam até nossa ignorância.

Visão, óptica, panorama, prisma,

Ângulo, cenário, perspectiva,

Nomenclaturas que apontam esse órgão dos sentidos,

Como textos revelados, aclarados e esclarecidos.

Olhares fulminantes

Sãoletais,

Ferem tanto quanto as palavras.

Já os flamejantes

São ardentes,

E abrasam até corações doentes.

Como nos relacionamos?

Olhamos mais máquinas ou humanos?

A máquina é fria, não revela, não atravessa,

O humano é organismo que age e reage,

Pulsante, latejante, palpitante, ele interage.

O choro lava, limpa, purifica, Às vezes, inevitável,

Outras, dispensável,

Por mágoa, discórdia, compaixão,

Dores físicas, pêsames ou perdão,

Traduz, simplesmente, o que sente o coração. 
Estrabismo, astigmatismo, hipermetropia, Glaucoma, miopia, presbiopia, Independente de graus, causas, sintomas, Óculos ou cirurgias de bons sentimentos, São tratamentos para a cura de relacionamentos. 


\section{Paixão}

Instinto ínsito

Ímpeto impulso

Salivas invasivas

De bocas incisivas.

Pele que expele

Essência que desvele

Recônditos ensejos

E tácitos desejos.

Coração acelerado, vozes veladas, Mãos frias, pupilas dilatadas,

De ávidos ardores,

Descortinando pudores.

Sopros, sussurros, Arrepios, calafrios, Febre que queima e teima arder, Embrenhada nas entranhas do ser.

Vicissitudes latentes,

Respiração, transpiração,

O sangue em pulsão,

Exercita e incita o coração.

Libidos poéticos, olhares platônicos

Apetece e reconhece

O que aquece, encandece,

Estremece, entorpece e tece 
Afrodíseos lapsos

Em diacrônicos colapsos. 


\section{Pitaia}

Com cores vibrantes, inebriantes, flamejantes,

E saltitantes ao olhar,

A pitaia vistosa e pomposa

Apetece ao paladar.

No entanto, o sabor destoa da cor,

$\mathrm{Na}$ fração de segundos do provar,

Denominador quase comum de frustração,

Produz um reprovar como comprovação.

Qual o ensinamento?

O legume sem perfume nos ensina

Que, acima do visual, é consensual

Que a essência, por excelência, é fundamental. 


\section{Poetize-se}

Verse, verseje,

Idealize, realize,

Viva poesia,

De sua autoria.

Transborde amor,

Por onde for,

Escreva e leia com arte,

Em qualquer parte.

Torne-se poético, épico,

Ético e até patético,

Poetizando memórias,

Com agradecimentos e dedicatórias.

Musicalize-se,

Ouça a música do coração,

Com rima ou sem rima,

Que exprima a obra-prima,

E que eternize a inspiração. 


\section{Sensorialidade}

A Química está no olfato, paladar.

A Física, na visão, audição.

A Química é visceral.

E na Física, elementos externos comparecem.

Quando nos apaixonamos e há reciprocidade, Pensamos haver Química, Mas a Física também se presentifica E harmonizada à Arte, a atração se identifica.

A junção dessas ciências com a Arte Expressam nossa complexidade, Em uma multissensorialidade.

Ora repletos, ora incompletos, Por vezes excessos, Porvezes excetos, Sempre seres inquietos. 


\section{Sociedade Enferma}

O mundo conectado encontra-se enfermo

Quais seriam as razões de tais desordens?

Não compartilhamos o real,

Mas o fragmento do real simulado,

Sendo tudo pré-configurado.

As lentes capturam contornos,

O manifesto não condiz com o existente,

Não expomos nossos segredos,

Compartilhamos nossos egos,

Um sentimento narcisista,

Reforçando as veleidades,

Com pseudo-realidades.

O tédio, o silêncio, a nostalgia,

A insônia, o cansaço, a melancolia,

Não são protagonistas

Nessa sociedade utopista.

A apoteose da exibição

Limita-se ao postado, ao publicado.

O que não é dito, o que não é manifesto,

O que não é fotografado,

Engendra a essência do ser,

Embora não se possa ver,

E ter essa consciência

Já configura a resiliência. 


\section{Tempo}

Como tornados, tormentas vividas, Tornam vidas movidas, removidas, Desprovidas, dissolvidas, E indevidamente absorvidas.

Intempéries inundam nosso ser E em cada entardecer, Seguimos sem transparecer, A fim de convalescer.

Secas, período de caos, Intrínsecas condolências, Extrínsecas indolências. Estiagens que resplendem resiliências.

Tempestades, nevascas, Condições climáticas extremas, $\mathrm{Na}$ alma, clamam calma, Como brisas sem trauma.

O tempo - não temperatura -, Pintura, leitura, literatura, Captura a sensação prematura, Como tessitura imatura, Ventilando novos ares, em branda releitura. 


\section{Trabalho}

Franklin já dizia que o trabalho dignifica o homem.

Weber, que o trabalho enobrece o homem.

Ambos o denotam como qualidades,

Na expansão de intrínsecas habilidades.

Seja ofício, exercício, ocupação,

Função, compromisso, realização,

O mister é labor,

Seja qual for,

Todos têm seu valor.

O trabalho é uma condição da existência humana,

Seja por conhecimento ou experiência que emana,

De práticas e ações congruentes,

Por indivíduos ou equipes polivalentes.

Pensar, refletir, projetar, elaborar,

São etapas que culminam em socializar

O desenvolvimento de competência técnica ou interpessoal,

De caráter condicional, situacional ou sazonal.

A luta, vem da labuta,

E o ócio nunca foi um bom negócio.

Trabalhar requer autoconhecimento,

E se for com comprometimento,

Planejamento e engajamento,

Haverá sempre bons desdobramentos.

A visão sistêmica expande as possibilidades, 
Como agentes transformadores da sociedade, Envoltos em enfrentamentos de toda natureza, Mesmo, em momentos, velejando contra a correnteza. 



\title{
SOBRE O LIVRO
}

Formato: $15,5 \times 23 \mathrm{~cm}$

Tipologia: Garamond

Número de Páginas: 62

Suporte do livro: e-Book

(C)

TODOS OS DIREITOS RESERVADOS

\author{
UNIVERSIDADE ESTADUAL DE GOIÁS \\ BR-153 - Quadra Área, Km 99 - 75.132-903 - Anápolis-GO \\ www.ueg.br / Fone: (62) 3328-1181
}

2019

Impresso no Brasil / Printed in Brazil 

livro Lira Lírica consiste em uma coletânea de 40 poemas que convidam à produção de sentidos, a partir de textos inquietantes. Por meio da arte em poesia, a leitura pretende despertar a sensibilidade e aguçar sensações aos leitores na apresentação de escritas polissêmicas, realçando a sintática e a semântica.

As temáticas que se apresentam são contemporâneas, com uma diversidade que promove um entretecer de sentimentos, desejos, considerações, que incitam interpretações intelectuais e afetivas, em uma concepção reflexiva da vida, reverberando afetos e pensamentos.

Lira Lírica é uma obra para ser apreciada e sentida por meio da fruição de uma leitura sinestésica, como sopros e sussurros na provocação de arrepios e calafrios silentes na alma de leitores sensíveis, amantes da literatura. 